\title{
Prevalence of anaemia and associated risk factors among pregnant women attending antenatal care in Gulu and Hoima Regional Hospitals in Uganda: A cross sectional study
}

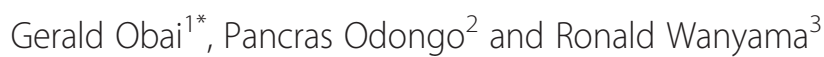

\begin{abstract}
Background: Anaemia is a public health problem affecting over 1.62 billion people globally. It affects all age groups of people and is particularly more prevalent in pregnant women. Africa carries a high burden of anaemia; in Uganda $24 \%$ of women of child bearing age have anaemia. Pregnant women living in poverty are at greater risk of developing iron deficiency anaemia. The objective of this study was to determine the prevalence of anaemia and the associated risk factors in pregnant women attending antenatal care at Gulu and Hoima Regional Hospitals in Northern and Western Uganda respectively.
\end{abstract}

Methods: We conducted a cross sectional study in Gulu and Hoima Regional Hospitals from July to October 2012. Our study participants were pregnant women attending antenatal care. Socio-demographic data were collected using structured questionnaires and blood samples were collected for haemoglobin estimation. Haemoglobin concentration was determined using an automated analyzer closed mode of blood sampling. Data were analysed using Stata version 12. Odds ratio was used as a measure of association, with $95 \%$ confidence interval; and independent risk factors for anaemia were investigated using logistic regression analyses. Ethical approval was obtained from Gulu University Research Ethics Committee and written informed consent was obtained from each study participant.

Results: The overall prevalence of anaemia was $22.1 \%$; higher in Gulu (32.9\%) than in Hoima (12.1\%), $p<0.001$. In Gulu, the prevalence of mild anaemia was $23 \%$, moderate anaemia was $9 \%$, and severe anaemia was $0.8 \%$, while in Hoima, the prevalence of mild anaemia was $9 \%$, moderate anaemia was $2.5 \%$, and severe anaemia was $0.5 \%$. Independent risk factors for anaemia were: being a housewife [Adjusted Odds Ratio (AOR) $=1.7,95 \% \mathrm{Cl}$ : 1.05-2.68]; and being a resident in Gulu (AOR $=3.6,95 \% \mathrm{Cl}: 2.41-5.58)$.

Conclusion: The prevalence of anaemia in pregnant women in Gulu is higher than in Hoima. Amongst pregnancy women, being a housewife is an independent risk factor for anaemia. Greater efforts are required to encourage early antenatal attendance from women in these at risk groups. This would allow iron and folic acid supplementation during pregnancy, which would potentially reduce the prevalence of anaemia.

Keywords: Anaemia, Gulu, Hoima, Hospital, Pregnant women, Prevalence

\footnotetext{
* Correspondence: lekobai@gmail.com

'Department of Physiology, Faculty of Medicine, Gulu University, P.O Box

166, Gulu, Uganda

Full list of author information is available at the end of the article
}

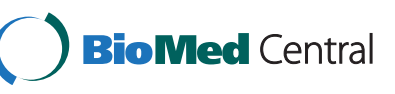

(c) 2016 Obai et al. Open Access This article is distributed under the terms of the Creative Commons Attribution 4.0 International License (http://creativecommons.org/licenses/by/4.0/), which permits unrestricted use, distribution, and reproduction in any medium, provided you give appropriate credit to the original author(s) and the source, provide a link to the Creative Commons license, and indicate if changes were made. The Creative Commons Public Domain Dedication waiver (http://creativecommons.org/publicdomain/zero/1.0/) applies to the data made available in this article, unless otherwise stated. 


\section{Background}

Anaemia is a global public health problem affecting over 1.62 billion people [1]. It affects all age groups of people but pregnant women and children are more vulnerable. Iron deficiency is the leading cause of anaemia among pregnant women globally [2]. Other causes of anaemia in pregnancy are heavy blood loss as may occur during menstruation and parasitic infections, conditions such as malaria and HIV which lower blood haemoglobin $(\mathrm{Hb})$ concentrations, and micronutrient deficiencies [1]. Low intake and poor absorption of iron especially during growth and pregnancy when iron requirements are higher remain risk factors for anaemia [3]. The World Health Organisation defines anaemia in pregnant women as $\mathrm{Hb}$ concentration less than $11.0 \mathrm{~g} / \mathrm{dl}$ [4]. In pregnant women, anaemia increases risk for maternal and child mortality and has negative consequences on the cognitive and physical development of children [5], and on work productivity $[6,7]$. Severe anaemia is associated with fatigue, weakness, breathlessness, dizziness, drowsiness and perceived paleness of the skin [8]. In the developing world, anaemia is a priority nutritional problem because of the economic, social, and other negative consequences associated with it [9]. Africa carries a high burden of anaemia with a prevalence of $65.8 \%$ among pregnant women [1]. In Uganda, the prevalence of anaemia among women of child bearing age has been reported to be $24 \%$ overall, and 13.1 and $18.8 \%$ in Northern and Western Uganda, respectively [10].

Poverty is one of the risk factors for iron deficiency in pregnant women $[11,12]$, and given the fact that Northern region is the poorest region in Uganda [13] with high rates of malnutrition, the problem of anaemia cannot be underestimated. Despite the known consequences of anaemia in pregnancy, there is scanty information on the prevalence of anaemia in pregnant women in Northern Uganda since the end of the Lord's Resistance Army (LRA) rebellion in 2006. The two decades of civil war in Northern Uganda led to the destruction of social services and left the majority of the population in poverty. Western Uganda on the other hand remained peaceful during the same period. It was therefore necessary to compare the prevalence of anaemia in the two regional hospitals. This would give an insight into the long term effect of the war on women of child bearing age. The objective of this study was to determine the prevalence of anaemia and associated risk factors among pregnant women attending antenatal care at Gulu and Hoima Regional Hospitals so that evidence-based interventions can be put in place.

\section{Methods}

\section{Study design and setting}

We conducted a cross sectional study at Gulu and Hoima Regional Hospitals from July to October 2012. Gulu and Hoima Regional Hospitals are located in
Northern and Western Uganda, respectively. Gulu district headquarters are located approximately $340 \mathrm{~km}$ North of Uganda's capital city, Kampala. The population of Gulu District is 443,733 [14]. The coordinates of the district are: $0245 \mathrm{~N}, 32$ 00E. Hoima district headquarters are located approximately $230 \mathrm{~km}$ Northwest of Kampala. The population of Hoima district is 573,903 [14]. The coordinates of the district are: $0124 \mathrm{~N}, 3118 \mathrm{E}$.

\section{Study population}

Our study participants were pregnant women attending antenatal care in the two regional hospitals. All pregnant women who consented to the study and who reported that they did not have sickle cell disease were eligible to participate in the study. This is because persons who have sickle cell disease usually have lower Hb levels than the normal persons.

\section{Sample size and sampling procedures}

The sample size for this study was calculated using Kish Leslie formula. We considered $95 \%$ confidence interval, $5 \%$ margin of error, and 45 and $64 \%$ prevalence of anaemia for Gulu (Northern Uganda) and Hoima (Western Uganda), respectively as was reported by Ugandan Demographic and Health surveys [15]. We factored a $10 \%$ non response rate in the sample size calculation. The two hospitals were purposively sampled since they are regional referral hospitals in the study areas with high patient load, from different backgrounds and settings. We used simple random sampling to select the study participants. Each day, before the provision of health education, the names of every pregnant woman attending the antenatal clinic was taken. Fifty percent of the women were then randomly selected until the required sample size was attained. The probability sampling was employed to avoid selection bias.

\section{Socio-demographic data}

Data on socio-demographic characteristics were collected using structured questionnaires (Additional file 1). The questionnaire was pre-tested in an area with similar settings to those of the study hospitals. The questionnaire was then refined to further improve its validity and reliability. The questionnaires were both in English and the local languages. Trained research assistants who were fluent in both English and the local language (Luo or Lunyoro) conducted face-to-face interviews with the pregnant women. The interviews were conducted in privacy to maintain confidentiality, within the hospital premises.

\section{Collection and analysis of blood samples}

The vein puncture site was cleaned using a swab containing $70 \%$ alcohol and using aseptic methods, an appropriate vein was identified and a hypodermic needle introduced into the vein. About 3-4 $\mathrm{ml}$ of venous blood was drawn 
Table 1 Socio-demographic characteristics of the study participants $(N=743)$

\begin{tabular}{|c|c|c|c|c|c|c|c|c|c|}
\hline \multirow[b]{2}{*}{ Characteristic } & \multicolumn{2}{|c|}{ Hoima $(N=387)$} & \multicolumn{2}{|c|}{ Gulu (N=356) } & \multicolumn{5}{|l|}{ Gravidity } \\
\hline & Number & Percent & Number & Percent & $1-4$ & 309 & 79.8 & 301 & 84.6 \\
\hline Age & & & & & $>4$ & 78 & 20.2 & 55 & 15.4 \\
\hline$\leq 19$ & 102 & 26.4 & 97 & 27.3 & Delivery gap & & & & \\
\hline $20-24$ & 116 & 30.0 & 127 & 35.7 & Never delivered & 130 & 33.6 & 120 & 33.7 \\
\hline $25-29$ & 91 & 23.5 & 87 & 24.4 & 1-11 months & 10 & 2.6 & 12 & 3.4 \\
\hline $30-34$ & 54 & 14.0 & 32 & 9.0 & $12-24$ & 75 & 19.4 & 41 & 11.5 \\
\hline $35-39$ & 22 & 5.7 & 9 & 2.5 & $25-36$ & 60 & 15.5 & 79 & 22.2 \\
\hline$>39$ & 2 & 0.5 & 4 & 1.2 & $>36$ & 112 & 28.9 & 104 & 29.2 \\
\hline
\end{tabular}

Table 1 Socio-demographic characteristics of the study participants $(N=743)$ (Continued)
Primary

Secondary

Tertiary

Still in school

Yes

No

Marital status

Married

Single

Widowed

Separated/divorced

Occupation

Farming

Trader

Formal employment

Handicraft

Housewife

Household size

1-5

6-10

$>10$

Wealth index

Lowest

Second lowest

Medium

High

Residence

Rural

Urban

Trimester

First

Second

Third

\section{6}

186

149

26

26

361

$$
6.7
$$

48.1

38.5

$$
6.7
$$$$
23
$$$$
204
$$$$
104
$$$$
25
$$

\section{7}

93.3

13

343

83.0

15.5

1.3

33.6

23.8

13.2

0.0

29.4

73.9

24.3

1.8

71.8

22.0

3.9

2.3

$42.4 \quad 137$

$57.6 \quad 219$

10.8

51.7

37.5
6.5

57.3

29.2

7.0

3.7

96.3

93.3

5.3

0.8

0.6

25.8

17.4

9.0

2.8

44.9

69.9

27.0

3.1

51.7

41.9

4.8

1.7

1.7

38.5

61.5

3.7

3.7
29.5

66.8 into a syringe and then transferred into a sterile vacutainer containing EDTA and transported to the laboratory for analysis. Trained laboratory technicians did the analyses both in Gulu and Hoima Regional Hospitals. Laboratory analysis was done using an automated analyser, (Celltac, Automated Haematology Analyzer, MEK-6400. NIHON KOHDEN). The manufacturer supplied controls were run every morning to ensure that the analyser was operating within 2.0 standard deviations. The closed mode of blood sampling was used; the analyser automatically sampled blood, processed, analysed and printed out the haemoglobin concentration levels. Pregnant women with haemoglobin concentration of less than $11.0 \mathrm{~g} / \mathrm{dl}$ were categorised as anaemic. Anaemia was considered severe when haemoglobin concentration was less than $7.0 \mathrm{~g} / \mathrm{dL}$, moderate when haemoglobin was between 7.0 and $9.9 \mathrm{~g} / \mathrm{dL}$, and mild from 10 to $10.9 \mathrm{~g} / \mathrm{dL}$ [4].

\section{Statistical analysis}

Both the laboratory and questionnaire data were checked and cleaned for completeness and consistency. Participants with missing data on haemoglobin level were excluded from the analyses. Statistical analysis was performed using Stata version 12. Quantitative variables were categorised into groups basing on either biologically recognised groupings

Table 2 Anaemia prevalence in Gulu and Hoima districts

\begin{tabular}{llr}
\hline District & Number & Percent \\
\hline Gulu & 117 & 32.9 \\
Total anaemia & 82 & 23.0 \\
Mild anaemia & 32 & 9.0 \\
Moderate anaemia & 3 & 0.8 \\
Severe anaemia & & \\
Hoima & 47 & 12.1 \\
Total anaemia & 35 & 9.0 \\
Mild anaemia & 10 & 2.5 \\
Moderate anaemia & 2 & 0.5 \\
Severe anaemia & & \\
\hline
\end{tabular}


Table 3 Chi- square tests of anaemia and associated risk factors among pregnant women in Gulu and Hoima Regional Hospitals

\begin{tabular}{|c|c|c|c|c|c|}
\hline \multirow[t]{2}{*}{ Variable } & \multicolumn{2}{|l|}{ Anaemic } & \multicolumn{2}{|c|}{ Non anaemic } & \multirow[t]{2}{*}{ P-value } \\
\hline & Number & Percentage & Number & Percentage & \\
\hline \multicolumn{6}{|l|}{$\overline{\text { Age }}$} \\
\hline$\leq 19$ & 47 & 23.6 & 152 & 76.4 & \\
\hline $20-24$ & 48 & 19.8 & 195 & 80.2 & 0.62 \\
\hline $25-29$ & 42 & 23.6 & 136 & 79.4 & \\
\hline $30-34$ & 21 & 24.4 & 65 & 75.6 & \\
\hline $35-39$ & 4 & 12.9 & 27 & 87.1 & $0.58^{b}$ \\
\hline$>39$ & 2 & 33.3 & 4 & 66.7 & \\
\hline \multicolumn{6}{|l|}{ Education } \\
\hline No education & 11 & 45.8 & 13 & 54.2 & \\
\hline Primary & 87 & 22.8 & 295 & 77.2 & $0.01^{\mathrm{a}}$ \\
\hline Secondary & 59 & 20.9 & 224 & 79.1 & \\
\hline Higher & 7 & 13.0 & 47 & 87.0 & \\
\hline \multicolumn{6}{|l|}{ Still in school } \\
\hline Yes & 3 & 7.7 & 36 & 92.3 & $0.03^{b}$ \\
\hline No & 161 & 22.9 & 543 & 77.1 & $0.03^{\mathrm{a}}$ \\
\hline \multicolumn{6}{|l|}{ Occupation } \\
\hline Farmer & 38 & 17.1 & 184 & 81.9 & \\
\hline Trader & 31 & 20.1 & 123 & 79.9 & $0.03^{\mathrm{a}}$ \\
\hline $\begin{array}{l}\text { Formal } \\
\text { employment }\end{array}$ & 15 & 18.1 & 68 & 81.9 & \\
\hline Handicraft & 3 & 30.0 & 7 & 70.0 & $0.03^{b}$ \\
\hline Housewife & 77 & 28.1 & 197 & 71.9 & \\
\hline \multicolumn{6}{|l|}{ Residence } \\
\hline Rural & 67 & 22.3 & 234 & 77.7 & 0.9 \\
\hline Urban & 97 & 22.0 & 345 & 78.0 & \\
\hline \multicolumn{6}{|l|}{ Marital status } \\
\hline Single & 14 & 17.7 & 65 & 82.3 & 0.2 \\
\hline Married & 145 & 22.2 & 508 & 77.8 & \\
\hline Widowed & 2 & 50.0 & 2 & 50.0 & $0.1^{b}$ \\
\hline Separated/divorced & 3 & 42.9 & 4 & 57.1 & \\
\hline \multicolumn{6}{|l|}{ District } \\
\hline Hoima & 47 & 12.1 & 340 & 87.9 & $<0.01^{\mathrm{a}}$ \\
\hline Gulu & 117 & 32.9 & 239 & 67.1 & \\
\hline \multicolumn{6}{|l|}{ Trimester } \\
\hline First & 8 & 14.6 & 47 & 85.4 & 0.2 \\
\hline Second & 63 & 20.7 & 242 & 79.3 & \\
\hline Third & 93 & 24.3 & 290 & 75.7 & \\
\hline \multicolumn{6}{|l|}{ Gravidity } \\
\hline $1-4$ & 133 & 21.8 & 477 & 78.2 & 0.7 \\
\hline$>5$ & 31 & 23.3 & 102 & 76.7 & \\
\hline \multicolumn{6}{|l|}{$\begin{array}{l}\text { Delivery gap } \\
\text { (months) }\end{array}$} \\
\hline Never delivered & 61 & 24.4 & 189 & 75.6 & 0.8 \\
\hline $1-11$ & 5 & 22.7 & 17 & 77.3 & \\
\hline $12-24$ & 23 & 19.8 & 93 & 80.2 & \\
\hline
\end{tabular}

Table 3 Chi- square tests of anaemia and associated risk factors among pregnant women in Gulu and Hoima Regional Hospitals (Continued)

\begin{tabular}{llllll}
\hline $25-36$ & 31 & 22.3 & 108 & 77.7 & \\
$>36$ & 44 & 20.4 & 172 & 79.6 & \\
Household size & & & & & \\
$1-5$ & 111 & 20.8 & 424 & 79.2 & 0.3 \\
$6-10$ & 48 & 25.3 & 142 & 74.7 & \\
$>10$ & 5 & 27.8 & 13 & 72.2 & \\
Wealth index & & & & & \\
Lowest & 100 & 21.7 & 362 & 78.3 & 0.7 \\
Second lowest & 56 & 23.9 & 178 & 76.1 & \\
Middle & 5 & 15.6 & 27 & 84.4 & \\
High & 3 & 20.0 & 12 & 80.0 & \\
\hline
\end{tabular}

${ }^{a}$ Statistically significant

${ }^{\mathrm{b}}$ Fisher's exact test

like trimester in pregnancy or societal recognised groupings like education levels. Descriptive statistics was employed for the analysis of demographic data. We used odds ratios as a measure of association, with a $95 \%$ confidence interval. Variables with p-values $<0.2$ at bivariable analysis and those with biological plausibility with respect to anaemia were put into backward stepwise multivariable logistic regressions to determine the independent predictors for anaemia in pregnancy. Statistical significance was set at $P<0.05$.

\section{Ethical considerations}

The study was approved by Gulu University Research Ethics Committee. Written informed consent was obtained from each study participant before data collection. Privacy and confidentiality was maintained throughout the study process.

\section{Results}

A total of 743 pregnant women took part in this study for a response rate of $91.1 \%$. Some participants withdrew from the study at the point of blood collection. A large majority of the study participants were below the age of 25 years (Table 1). A total of 164 (22.1\%) women were anaemic. The prevalence of anaemia in Gulu was $32.9 \%$ (117/ 356) and that in Hoima was $12.1 \%$ (47/387). The prevalence of mild, moderate and severe anaemia in Gulu were 23, 9, and $0.8 \%$ respectively; and in Hoima were $9,2.5$, and $0.5 \%$, respectively (Table 2). In the bivariable analysis, anaemia was significantly associated with the level of education attained, occupation, being in or out of school, and being a resident of Gulu district (Table 3). Being a housewife (AOR = 1.7, $95 \% \mathrm{CI}: 1.05-2.68)$ and a resident in Gulu districts ( $\mathrm{AOR}=3.6,95 \% \mathrm{CI}: 2.41-5.58)$ were independent risk factors for anaemia (Table 4). 
Table 4 Multivariable logistic regression analysis for risk factors for anaemia in Gulu and Hoima Regional Hospitals

\begin{tabular}{|c|c|c|c|c|}
\hline Variable & Number & Anaemic (\%) & $\begin{array}{l}\text { Crude OR } \\
(95 \% \mathrm{Cl})\end{array}$ & AOR (95 \% Cl) \\
\hline \multicolumn{5}{|l|}{ Age } \\
\hline$<20$ & 199 & 47 (23.6) & 1.0 & 1.0 \\
\hline $20-24$ & 243 & 48 (19.8) & $0.8(0.51-1.60)$ & $1.8(0.50-1.32)$ \\
\hline $25-29$ & 178 & $42(23.6)$ & $1.0(0.62-1.61)$ & $1.1(0.63-1.80)$ \\
\hline $30-34$ & 86 & $21(24.4)$ & $1.0(0.58-1.89)$ & $1.3(0.68-2.56)$ \\
\hline $35-39$ & 31 & $4(12.9)$ & $0.5(0.16-1.45)$ & $0.6(0.19-1.85)$ \\
\hline$\geq 40$ & 6 & $2(33.3)$ & $1.6(0.29-9.16)$ & $1.4(0.22-8.99)$ \\
\hline \multicolumn{5}{|l|}{ Education } \\
\hline No education & 24 & $16(32.7)$ & 1.0 & 1.0 \\
\hline Primary & 382 & $86(22.1)$ & $0.3(0.15-0.81)$ & $0.5(0.27-1.10)$ \\
\hline Secondary & 283 & $55(21.7)$ & $0.3(0.13-0.74)$ & $0.6(0.30-1.31)$ \\
\hline Higher & 547 & $7(13.0)$ & $0.2(0.52-0.60)$ & $0.4(0.11-1.20)$ \\
\hline \multicolumn{5}{|l|}{ Occupation } \\
\hline Farmer & 222 & $38(17.1)$ & 1.0 & 1.0 \\
\hline Trader & 154 & $31(20.1)$ & $1.2(0.72-2.07)$ & $1.3(0.73-2.21)$ \\
\hline $\begin{array}{l}\text { Formal } \\
\text { employment }\end{array}$ & 83 & $15(18.1)$ & $1.1(0.55-2.07)$ & $1.4(0.63-2.96)$ \\
\hline Handicraft & 10 & $3(30.0)$ & $2.1(0.51-8.44)$ & $1.1(0.25-4.45)$ \\
\hline Housewife & 274 & $77(28.1)$ & $1.9(1.22-2.94)$ & $1.7(1.05-2.68)$ \\
\hline \multicolumn{5}{|l|}{ Residence } \\
\hline Rural & 301 & $67(22.3)$ & 1.0 & \\
\hline Urban & 442 & $97(22.0)$ & $1.0(0.69-1.40)$ & \\
\hline \multicolumn{5}{|l|}{ Marital status } \\
\hline Single & 79 & $14(17.7)$ & 1.0 & 1.0 \\
\hline Married & 653 & $145(22.2)$ & $1.3(0.72-2.43)$ & $0.8(0.43-1.64)$ \\
\hline Widowed & 4 & $2(50)$ & $4.6(0.58-37.46)$ & $2.0(0.21-18.89)$ \\
\hline $\begin{array}{l}\text { Separated/ } \\
\text { divorced }\end{array}$ & 7 & $3(42.9)$ & $3.0(0.68-17.92)$ & $3.0(0.55-16.85)$ \\
\hline \multicolumn{5}{|l|}{ District } \\
\hline Hoima & 387 & $47(12.1)$ & 1.0 & 1.0 \\
\hline Gulu & 356 & $117(32.9)$ & $3.5(2.40-5.23)$ & $3.6(2.41-5.58)$ \\
\hline \multicolumn{5}{|l|}{ Trimester } \\
\hline First & 55 & $8(14.6)$ & 1.0 & 1.0 \\
\hline Second & 305 & $63(20.7)$ & $1.5(0.69-3.41)$ & $1.5(0.63-3.39)$ \\
\hline Third & 383 & $93(24.3)$ & $1.9(0.86-4.14)$ & $1.2(0.52-2.74)$ \\
\hline \multicolumn{5}{|l|}{ Gravidity } \\
\hline $1-4$ & 610 & $133(21.80)$ & 1.0 & \\
\hline$\geq 5$ & 133 & $31(23.3)$ & $1.1(0.70-1.70)$ & \\
\hline \multicolumn{5}{|l|}{ Delivery gap } \\
\hline None & 250 & $61(24.2)$ & 1.0 & \\
\hline $1-11$ & 22 & $5(22.7)$ & $0.9(0.32-2.58)$ & \\
\hline $12-24$ & 116 & $23(19.8)$ & $0.8(0.45-1.32)$ & \\
\hline $25-36$ & 139 & $31(22.3)$ & $0.9(0.54-1.46)$ & \\
\hline$>36$ & 216 & $44(20.4)$ & $0.8(0.51-1.23)$ & \\
\hline
\end{tabular}

Table 4 Multivariable logistic regression analysis for risk factors for anaemia in Gulu and Hoima Regional Hospitals (Continued)

\begin{tabular}{|c|c|c|c|c|}
\hline \multicolumn{5}{|l|}{ Household size } \\
\hline $1-5$ & 535 & 11120.8 & 1.0 & \\
\hline $6-10$ & 190 & 4825.3 & $1.3(0.25-1.79)$ & \\
\hline$>10$ & 18 & 527.8 & $1.5(0.51-4.21)$ & \\
\hline \multicolumn{5}{|l|}{ Wealth index } \\
\hline Lowest & 462 & $100(21.7)$ & 1.0 & \\
\hline Second lowest & 234 & $56(23.9)$ & $1.1(0.78-1.66)$ & \\
\hline Middle & 32 & $5(15.6)$ & $0.7(0.25-1.79)$ & \\
\hline High & 15 & $3(20.0)$ & $0.9(0.25-3.27)$ & \\
\hline \multicolumn{5}{|l|}{ Still in school } \\
\hline Yes & 39 & $3(7.7)$ & 1.0 & 1.0 \\
\hline No & 704 & $161(22.9)$ & $3.7(1.11-12.10)$ & $2.6(0.73-9.26)$ \\
\hline
\end{tabular}

\section{Discussion}

The overall prevalence of anaemia was $22.1 \%$ which agrees with findings in Ethiopia and Nigeria, $[16,17]$ but lower than those reported elsewhere [18-21], and the WHO estimate of $40-60 \%$ in developing countries [1]. The variations in the prevalence of anaemia may be due to the fact that the interventions employed to address anaemia in pregnancy vary in different settings.

The prevalence of anaemia was significantly higher in Gulu than in Hoima $(P<0.001)$. Gulu district was ravaged by a twenty-year war between the LRA and the Government of Uganda that left most of the social services in the district in ruins and a large majority of its population in poverty [22]. Our findings also show that being a housewife is an independent risk factor for anaemia. Because most housewives depend solely on their husbands' earnings for their financial needs, the majority of them tend to be of low socioeconomic status which has been reported as a known determinant of anaemia [23, 24]. This is also manifested by the finding that anaemia was more prevalent among women who had low monthly family income. Anaemia was also more prevalent among women who live in big households ( $>5$ people) compared to those who live in small households. These might be low income families that were displaced from their family land during the LRA insurgency but have since decided to remain in the urban settings for a better life. Education level attained was also found to be associated with anaemia. In Uganda, low level of education is associated with unemployment, which consequently leads to poverty, a known risk factor for anaemia in pregnancy [21, 24].

Anaemia prevalence was highest $(24.3 \%)$ during the third trimester as compared to the first trimester $(14.6 \%)$ and second trimester (20.7 \%). Haemodilution 
in pregnancy increases to peak during the second trimester which may explain the high prevalence of anaemia during this period. However, the increased incidence of anaemia during the third trimester may also indicate poor antenatal care and nutrition. These findings agree with that of Karaoglu and the WHO report [23, 25], but differ to those from Porto Novo, Cape Verde and Abeokuta, Nigeria [24, 26]. Although a study conducted in Trinidad and Tobago reported increased presence of anaemia with increasing gravidity [27], this study found no evidence of increased incidence of anaemia in a grand multigravid woman as compared to primigravid, secundigravid or multigravid woman. This finding is in agreement with other studies [16]. Perhaps the health education provided to pregnant women during antenatal visits leads to better health seeking behaviour and dietary habits, especially during pregnancy.

These findings will go a long way in addressing the problem of anaemia, which can affect psychological and physical behaviour. This is especially important because even very mild forms of anaemia have been reported to influence the sense of well being, lessen resistance to fatigue, lower productivity [28], aggravate other disorders, and affect work capacity [26]. In pregnant women, anaemia can result in increased risk of maternal and perinatal mortality, low birth weight, [29] and reduced resistance to blood loss with the result that death may occur from the blood loss associated with delivery. The strength of this study is the use of power formula to calculate the sample size and the random sampling of the study participants which enhances its generalisability.

\section{Limitations of this study}

We did not consider other factors like parasitic infections which can lead to anaemia. We were therefore not able to determine their contribution to anaemia in our study population. Being a cross sectional study, we could not identify the cause and effect relationship.

\section{Conclusion}

The prevalence of anaemia in pregnant women in Gulu is higher than in Hoima. Amongst pregnancy women, being a housewife is an independent risk factor for anaemia. Greater efforts are required to encourage early antenatal attendance from women in these at risk groups. This would allow iron and folic acid supplementation during pregnancy, which would potentially reduce the prevalence of anaemia.

\section{Additional file}

Additional file 1: Questionnaire (English version). (PDF $1303 \mathrm{~kb}$ )

\section{Abbreviations}

AOR: adjusted odds ratio; Hb: haemoglobin; HIV: human immuno-deficiency virus; LRA: Lord's Resistance Army; WHO: World Health Organisation.

Competing interests

The authors declare that they have no competing interests.

\section{Authors' contributions}

GO participated in designing the study, data collection, and statistical analyses and served as the lead author of the manuscript. RW conceived and participated in designing the study, data collection and data entry. PO participated in designing the study, data collection and proof read the manuscript. All authors read and approved the final manuscript.

\section{Acknowledgements}

We are grateful to Dr Benjamin Hopwood, Medical Officer, Paediatric Department, Hoima Regional Referral Hospital, who edited the manuscript to address typographical and grammatical errors. This work was supported by Training Health Researchers into Vocational Excellence in East Africa (THRiVE); grant number 087540 funded by the Welcome Trust. Its contents are solely the responsibility of the authors and do not necessarily represent the official views of the supporting offices.

\section{Author details}

${ }^{1}$ Department of Physiology, Faculty of Medicine, Gulu University, P.O Box 166, Gulu, Uganda. ${ }^{2}$ Department of Internal Medicine, Hoima Regional Hospital, P.O Box 5, Hoima, Uganda. ${ }^{3}$ Department of Biochemistry, Faculty of Medicine, Gulu University, P.O Box 166, Gulu, Uganda.

Received: 20 May 2015 Accepted: 7 April 2016

Published online: 11 April 2016

\section{References}

1. World Health Organisation. Worldwide prevalence of anaemia 1993-2005. WHO Global Database on Anaemia. Geneva: WHO; 2008.

2. World Health Organization. The World Health Report 2002: reducing risks, promoting healthy life. Geneva: WHO; 2002.

3. Cusick SE, Mei Z, Freedman DS, Looker AC, Ogden CL, Gunter E, et al. Unexplained decline in the prevalence of anemia among US children and women between 1988-1994 and 1999-2002. Am J Clin Nutr. 2008;88:1611.

4. WHO. Haemoglobin concentrations for the diagnosis of anaemia and assessment of severity. Vitamin and Mineral Nutrition Information System. Geneva: WHO; 2011. http://www.who.int/vmnis/indicators/haemoglobin.pdf. Accessed 24 Dec 2015.

5. Halterman JS, Kaczorowski JM, Aligne CA, Auinger P, Szilagyi PG. Iron deficiency and cognitive achievement among school-aged children and adolescents in the United States. Pediatrics. 2001;107:1381-6.

6. Haas JD, Brownlie T. Iron deficiency and reduced work capacity: a critical review of the research to determine a casual relationship. J Nutr. 2001;131:2S-2.

7. Verdon F, Burnand B, Stubi CL, Bonard C, Graff M, Michaud A, et al. Iron supplementation for unexplained fatigue in non-anaemic women: double blind randomised placebo controlled trial. BMJ. 2003;326(7399):1124.

8. Gies S, Brabin BJ, Yassin MA, Cuevas LE. Comparison of screening methods for anaemia in pregnant women in Awassa, Ethiopia. Trop Med Int Health. 2003:8(4):301-9.

9. Jamil KM, Rahman AS, Bardhan PK, Khan Al, Chowdhury F, Sarker SA, et al. Micronutrients and anaemia. J Health Popul Nutr. 2008;26(3):340-55.

10. Uganda Bureau of Statistics (UBOS) and ICF International Inc. Uganda Demographic and Health Survey 2011. 2012. ICF International Inc.: Kampala; UBOS and Calverton: Maryland.

11. Bodnar LM, Cogswell ME, Scanlon KS. Low income postpartim women are at risk of iron deficiency. J Nutr. 2002;132(8):2298-302.

12. U.S. Preventive Services Task Force. Screening for iron deficiency anemia, including iron supplementations for children and pregnant women: recommendation statement. Am Fam Physician. 2006;74(3):461-4.

13. Uganda Bureau of Statistics (UBOS), ICF Macro. Uganda Malaria Indicator Survey 2009. Calverton: UBOS and ICF Macro; 2010.

14. Uganda Bureau of Statistics. National Population and Housing Census 2014. Kampala: UBOS; 2014. http://www.ubos.org/onlinefiles/uploads/ubos/NPHC/ 
NPHC\%202014\%20PROVISIONAL\%20RESULTS\%20REPORT.pdf. Accessed 5 Jan 2016.

15. Uganda Bureau of Statistics (UBOS), Macro International Inc. Uganda Demographic and Health Survey 2006. Calverton: UBOS and Macro International Inc; 2007.

16. Buseri Fl, Uko EK, Jeremiah ZA, Usanga EA. Prevalence and risk factors of anaemia among pregnant women in Nigeria. Open Hematol J. 2008;2:14-9.

17. Alem M, Enawgaw B, Gelaw A, Kena T, Seid M, Olkeba Y. Prevalence of anemia and associated risk factors among pregnant women attending antenatal care in Azezo Health Center Gondar town, Northwest Ethiopia. J Interdiscip Histopathol. 2013;1(3):137-44.

18. Ahmad N, Kalakoti P, Bano R, Syed MMA. The prevalence of anaemia and associated factors in pregnant women in a rural Indian community. AMJ. 2010;3(5):276-80.

19. Getachew M, Yewhalaw D, Tafess K, Getachew Y, Ahmed ZA. Anaemia and associated risk factors among pregnant women in Gilgel Gibe dam area, Southwest Ethiopia. Parasites Vectors. 2012;5:296.

20. Hoque M, Kader SB, Hoque E. Prevalence of anaemia in pregnancy in the Uthungulu health district of KwaZulu-Natal, South Africa. SA Fam Pract. 2007;49:6.

21. Lokare PO, Karanjekar VD, Gattani PL, Kulkarni AP. A study of prevalence of anemia and sociodemographic factors associated with anemia among pregnant women in Aurangabad city, India. Nigerian Med. 2012;6(1):30-4.

22. Economic Development Policy and Research Department. Poverty status report 2014: Structural Change and Poverty Reduction in Uganda. Kampala: Ministry of finance, planning and economic development; 2014

23. Karaoglu L, Pehlivan R, Egri M, Deprem C, Gunes G, Genc FM, et al. The prevalence of nutritional anemia in pregnancy in an east Anatolian province, Turkey. BMC Public Health. 2010;10:329.

24. Idowu OA, Mafiana CF, Sotiloye D. Anaemia in pregnancy: a survey of pregnant women in Abeokuta, Nigeria. Afr Health Sci. 2005;5(4):295-9.

25. WHO. The prevalence of anaemia in women: a tabilation of available information. Geneva: WHO; 1992.

26. Okeke PU. Anaemia in pregnancy-is it a persisting public health problem in Porto Novo-Cape Verde? Res J Med Sci. 2011;5(4):193-9.

27. Uche-Nwachi EO, Odekunle A, Jacinto S, Burnett M, Clapperton M, David Y, et al. Anaemia in pregnancy: associations with parity, abortions and child spacing in primary healthcare clinic attendees in Trinidad and Tobago. Afr Health Sci. 2010;10(1):66-70.

28. Balarajan Y, Ramakrishnan U, Ozaltin E, Shankar AH, Subramanian SV. Anaemia in low-income and middle-income countries. Lancet. 2011;378: 2123-35.

29. Kozuki N, Lee AC, Katz J. Moderate to severe, but not mild, maternal anemia is associated with increased risk of small-for-gestational-age outcomes. J Nutr. 2012;142:358-62.

\section{Submit your next manuscript to BioMed Central and we will help you at every step:}

- We accept pre-submission inquiries

- Our selector tool helps you to find the most relevant journal

- We provide round the clock customer support

- Convenient online submission

- Thorough peer review

- Inclusion in PubMed and all major indexing services

- Maximum visibility for your research

Submit your manuscript at www.biomedcentral.com/submit

) Biomed Central 